\title{
Penerapan Model Pembelajaran Problem Based Learning (PBL) pada Pembelajaran IPA
}

\author{
${ }^{1}$ Kholida Ismatulloh, ${ }^{2}$ Ropikoh \\ ${ }^{1}$ Prodi Pendidikan Informatika, FMIPA, Universitas Hamzanwadi, Jln. TGKH. M. Zainuddin \\ Abdul Madjid No. 132 Pancor Selong, Lombok Timur, NTB, 83611 \\ ${ }^{2}$ SMPN 3 Selong, Jln. Pahlawan, Selong Lombok Timur, NTB, 83611 \\ Email Korespondensi: kholida.ebtaryadi@gmail.com
}

\begin{tabular}{|c|c|}
\hline Arti & \\
\hline $\begin{array}{l}\text { Article History } \\
\text { Received: } 15 \mathrm{No} \\
\text { Revised: } 24 \mathrm{Dec} \\
\text { Published: } 30 \mathrm{D}\end{array}$ & \multirow{2}{*}{ 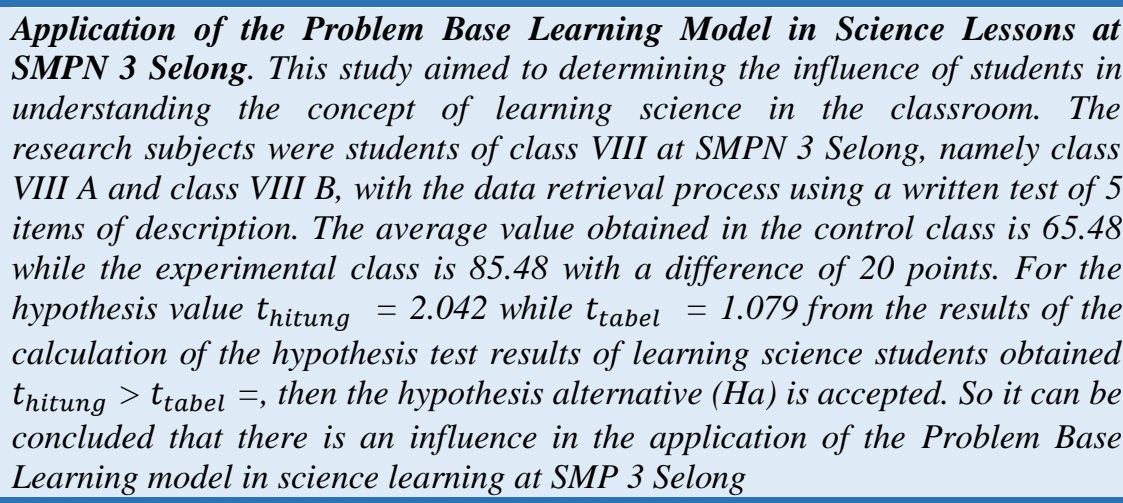 } \\
\hline $\begin{array}{l}\text { Key } \\
\text { Prol } \\
(P B 1 \\
\text { Leal }\end{array}$ & \\
\hline Artikel & Abstrak \\
\hline $\begin{array}{l}\text { Sejar: } \\
\text { Diteri } \\
\text { Direvi } \\
\text { Dipub }\end{array}$ & \multirow{2}{*}{$\begin{array}{l}\text { Penelitian yang berjudul "Penerapan Model Pembelajaran Problem Base } \\
\text { Learning (PBL) Pada Pelajaran IPA Di SMPN } 3 \text { Selong" bertujuan untuk } \\
\text { mengetahui sebagaimana pengaruh siswa- siswi dalam memahami konsep } \\
\text { pembelajaran IPA di dalam kelas. Subyek penelitian adalah siswa- siswi kelas } \\
\text { VIII di SMPN } 3 \text { Selong yaitu kelas VIII A dan kelas VIII B, dengan proses } \\
\text { pengambilan data menggunakan tes tertulis sebanyak } 5 \text { butir soal uraian. Nilai } \\
\text { rata- rata yang diperoleh di kelas kontrol } 65.48 \text { sedangkan kelas eksperimen } \\
\text { sebesar } 85.48 \text { dengan selisih perbendingan sebesar } 20 \text { poin. Untuk nilai } \\
\text { hipotesis } t_{\text {hitung }}=2,042 \text { sedangkan } t_{\text {tabel }}=1,079 \text { dari hasil perhitungan uji } \\
\text { hipotesis hasil belajar IPA peserta didik didapatkan nilai } t_{\text {hitung }}>t_{\text {tabel }} \text {, maka } \\
\text { hipotesis alternatif (Ha) diterima. Maka dapat ditarik kesimpulan bahwa ada } \\
\text { pengaruh dalam penerapan model pembelajaran Problem Base Learning (PBL) } \\
\text { dalam pembelajaran IPA di SMP } 3 \text { Selong. }\end{array}$} \\
\hline $\begin{array}{l}\text { Kata kunci } \\
\text { Problem Base Lear } \\
\text { (PBL); Pembelajaran } \\
\text { Hasil belajar. }\end{array}$ & \\
\hline
\end{tabular}

Sitasi: Ismatulloh, K., \& Ropikoh, R. (2021), Penerapan Model Pembelajaran Problem Base Learning (PBL) pada Pembelajaran IPA Di SMP 3 Selong, Kappa Journal. 5(2), 246-250.

\section{PENDAHULUAN}

Menurut (Trianto,2010:1) "pendidikan yang mampu menjawab tujuan nasional adalah pendidikan yang mampu mendukung pembangunan di masa mendatang, pendidikan yang mampu mengembangkan potensi peserta didik sehingga yang bersangkutan mampu menghadapi dan memecahkan masalah kehidupan yang dihadapinya dan pendidikan yang mampu menyentuh potensi nurani maupun kompetensi peserta didik". Pendidikan yang baik adalah pendidikan yang tidak hanya mempersiapkan peserta didiknya untuk suatu profesi atau jabatan, tetapi hendaknya siswanya dipersiapkan untuk menyelesaikan masalahmasalah yang dihadapinya dalam kehidupan sehari-hari. Terkait dengan hal tersebut kegiatan proses belajar-mengajar dikelas seharusnya menerapkan suatu strategi belajar yang kreatif 
dan inovatif sehingga dapat membantu siswa untuk memahami materi ajar dan aplikasi serta relevansinya dalam kehidupan sehari-hari.

Ilmu pengetahuan alam merupakan mata pelajaran yang mengkoordinasikan berbagai disiplin ilmu sublintas mata pelajaran seperti biologi, fisika, kimia, geologi, dan antariksa. Selain itu dalam kondisi ketergantungan hidup manusia akan ilmu dan teknologi yang sangat tinggi, maka pembelajaran IPA di SD harus dijadikan sebagai mata pelajaran dasar dan diarahkan untuk menghasilkan warga Negara yang melek IPA (Julia Rikawati;2014). Sebenarnya ilmu pengetahuan alam dapat juga dipadukan dengan mata pelajaran lain di luar bidang kajian ilmu pengetahuan alam, karena ilmu pengetahuan alam bukan sekedar gabungan dari biologi, fisika, kimia, dan antariksa tetapi juga merupakan integrasi kajian ilmu alamiah (Mujakir, 2015). Aspek pokok dalam pembelajaran IPA adalah siswa mampu menyadari keterbatasan dalam memahami pembelajaran di kelas dan meningkatkan rasa ingin tahu pada masalah- masalah yang timbul dalam proses pembelajaran di dalam kelas. Kedudukan guru sangatlah penting dalam hal tersebut, guru diminta harus lebih berinovasi dan berfariatif dalam menggunakan model pembelajaran yang akan dignakan dalam proses pembelajaran dalam kelas, salah satunya dengan menggunakan model pembelajaran Problem Base Learning (PBL).

PBL merupakan suatu pendekatan pembelajaran yang menggunakan masalah dunia nyata sebagai suatu konteks bagi peserta didik untuk belajar tentang cara berpikir kritis dan keterampilan pemecahan masalah, serta untuk memperoleh pengetahuan dan konsep yang esensial dari materi pelajaran.

Menurut Arends (2008:55), langkah-langkah dalam melaksanakan PBL ada 5 fase yaitu (1) mengorientasi siswa pada masalah; (2) mengorganisasi siswa untuk meneliti; (3) membantu investigasi mandiri dan berkelompok; (4) mengembangkan dan menyajikan hasil karya; (5) menganalisis dan mengevaluasi proses pemecahan masalah., permasalahan yang digunakan dalam PBL adalah permasalahan yang dihadapi di dunia nyata. Meskipun kemampuan individual dituntut bagi setiap siswa, tetapi dalam proses belajar dalam PBL siswa belajar dalam kelompok untuk memahami persoalan yang dihadapi. Kemudian siswa belajar secara individu untuk memperoleh informasi tambahan yang berhubungan dengan pemecahan masalah. Peran guru dalam PBL yaitu sebagai fasilitator dalam proses pembelajaran.

Untuk mencapai tujuan pembelajaran yang diinginkan maka dititik beratkan pada upaya dan usaha guru dalam mendorong dan membiasakan diri untuk lebih berfikir kreatif dan strategi apa saja yang akan digunakan di dalam kelas sehingga peserta didik gampang dalam menyerap pelajaran dan tidak gampang bosan belajar IPA. Penerapan metode pembelajaran PBL ini diharapkan mampu memberikan kontribusi terhadap prestasi belajar peserta didik khususnya dalam pembelajaran IPA, dikarenakan dalam metode- metode sebelumnya pembelajaran IPA dianggap sulit sekali untuk bisa cocok digunakan di dalam proses belajar mengajar. Peneliti memilih menerapkan metode PBL dikarenakan pada metode ini peserta didik dituntut untuk memecahkan suatu permasalahan yang dihadapi dalam dunia nyata dan sering ditemui dalam kehidupan sehari- hari sesuai sekali dengan pembelajaran IPA. Diharapkan dengan diterapkannya metode PBL bisa memberikan pengaruh baik dalam prestasi maupun motivasi belajar IPA peserta didik kelas VIII di SMP 3 Selong.

\section{METODE}

Penelitian ini dilakukan pada bulan Juli minggu ke dua tahun 2021, dengan subyek penelitian siswa- siswi kelas VIII SMP 3 Selong, peneliti mengambil sampel penelitian di kelas VIII A sebagai kelas Eksperimen dan VIII B untuk kelas control, dimana masingmasing kelas siswanya berjumlah 30 orang. Lokasi penelitian di SMPN 3 Selong. Metode penelitian yang digunakan adalah kuantitatif. Desain penelitian dibagi menjadi dua 
kelas yaitu kelas kontrol dengan metode biasa yang digunakan oleh guru setempat dan kelas eksperimen dengan menggunakan model pembelajaran PBL. Pengumpulan data menggunakan tes kemampuan kognitif berbentuk uraian. Uji coba instrument dilaksanakan di SMP Lab.Hamzanwadi Selong kelas VIII A dan B dengan menunjukkan hasil bahwa soal yang telah dibuat valid dan realibel. Perhitungan validitas uji coba instrument dari 10 butir soal yang diujikan ternyata 5 butir soal yang valid dan 5 butir soal yang tidak valid.

\section{HASIL DAN PEMBAHASAN}

Berdasarkan hasil analisis data penelitian didapatkan nilai rata- rata antara kelas kontrol dan kelas eksperimen pada tabel berikut:

Tabel 1. Data nilai kelas kontrol dan kelas eksperimen.

\begin{tabular}{ccc}
\hline Jumlah Siswa & Kelas Kontrol & Kelas Eksperimen \\
\hline 30 & 65.48 & 85.48 \\
\hline
\end{tabular}

Berdasarkan data tabel diatas bahwa nilai kelas kontrol 65.48 dan kelas ekseperimen 85.48 maka dapat diartikan bahwa kelas eksperimen dengan menggunakan model pembelajaran PBL lebih tinggi dibandingkan kelas kontrol. Model pembelajaran PBL lebih efektif digunakan dalam pembelajaran IPA. Menurut Nisaul dkk (2016) Model pembelajaran PBL adalah model pembelajaran yang berpusat pada siswa dimana siswa berupaya menemukan pemecahan masalah dengan menggunakan informasi dari berbagai sumber serta pengalaman sehari- hari. Menurut Ni Made (2008:76) PBL adalah model pembelajaran berbasis masalah adalah pembelajaran yang mengajarkan siswa bagaimana menggunakan konsep interaksi untuk menilai apa yang ingin diketahui, mengumpulkan informasi dan secara kolaborasi mengevaluasi hipotesisnya berdasarkan data yang telah dikumpulkan. Model pembelajaran PBL tepat sekali digunakan dalam pembelajaran IPA dikarenakan pembelajaran IPA lebih banyak menyelesaikan suatu kasus masalah yang biasa ditemukan dikehidupan sehari- hari. Itu yang menyebabkan hasil belajar siswa menjadi lebih baik dibandingkan proses pembelajaran secara konvensional dengan menggunakan metode ceramah. Dari hasil analisis atau perhitungan yang dilakukan, maka di dapatkan nilai dari chi kuadrat masing-masing kelas, kelompok dan sel. Hasil analisis tersebut dapat di lihat dalam tabel rangkuman dibawah ini.

Tabel 2. Keputusan Uni Chi Kuadrat

\begin{tabular}{lcccl}
\hline Kelas & $\begin{array}{l}\text { Jumlah } \\
\text { Responden }\end{array}$ & $\mathbf{X}^{\mathbf{2}}$ hitung & $\mathbf{X}^{\mathbf{2}}$ tabel & Keputusan \\
\hline Kontrol & 30 & -19.73 & 11,070 & $\begin{array}{l}\text { Terdistribusi } \\
\text { Normal }\end{array}$ \\
\hline Eksperimen & 30 & $-29,87$ & 11,070 & $\begin{array}{l}\text { Terdistribusi } \\
\text { Normal }\end{array}$ \\
\hline
\end{tabular}

Berdasarkan kriteria yang ada yaitu $F_{\text {hitung }<} F_{\text {tabel }}$ apabila maka kedua kelompok tersebut berasal dari sampel homogen, artinya kedua kelompok mempunyai kemampuan awal yang sama. Berikut disajikan rangkuman perhitungan dengan menggunakan Uji Varians:

Tabel 3 Rangkuman Uji Homogenitas Data Hasil Belajar IPA Siswa

\begin{tabular}{llllccl} 
No & Kelas & $\overline{\boldsymbol{X}}$ & SD & $\boldsymbol{F}_{\text {hitung }}$ & $\boldsymbol{F}_{\text {tabel }}$ & Keputusan \\
\hline 1. & Kontrol & 51,5 & 12,91 & 1.27 & 2.278 & Homogen \\
\hline 2. & Eksperimen & 56,5 & 14,56 & & & Homogen \\
\hline
\end{tabular}


Setelah terpenuhi persyaratan analisis tersebut, maka dapat dilakukan uji hipotesis untuk memenuhi apakah hipotesis yang telah di ajukan diterima atau ditolak. Dari perhitungan data diperoleh seperti pada tabel di bawah ini:

Tabel 4 Hasil Uji Hipotesis Data Hasil Belajar IPA Siswa

\begin{tabular}{llllll}
\hline No & Kelas & N (sampel) & $\begin{array}{l}\text { Standar } \\
\text { Deviasi } \\
\text { (SD) }\end{array}$ & $\boldsymbol{t}_{\text {hitung }}$ & $\boldsymbol{t}_{\text {tabel }}$ \\
\cline { 1 - 4 } 1. & Kontrol & 30 & 12,91 & 2,042 & 1,079 \\
\hline 2. & Eksperimen & 30 & 14,56 & & \\
\hline
\end{tabular}

Dari tabel diatas dapat diketahui nilai $\boldsymbol{t}_{\text {hitung }}=2,042$ sedangkan $\boldsymbol{t}_{\text {tabel }}=1,079$ dari hasil perhitungan uji hipotesis hasil belajar IPA siswa didapatkan nilai $\boldsymbol{t}_{\text {hitung }}>\boldsymbol{t}_{\text {tabel }}$, maka hipotesis alternatif (Ha) diterima. Maka dapat ditarik kesimpulan bahwa ada pengaruh penerapan model pembelajaran PBL dalam pembelajaran IPA di SMP 3 Selong. Hal ini sejalan dengan penelitian yaitu model PBL merupakan salah satu model pembelajaran yang memberikan pengaruh yang positif terhadap peningkatan prestasi belajar fisika khususnya peserta didik yang memiliki motivasi belajar tinggi. (Lestari, 2012). Hasil penelitian menggunakan PBL meningkatkan motivasi belajar mahasiswa dalam pembelajaran Fisika Dasar 1 (Hadma Yuliani, 2021). Penelitian lain dilakukan oleh Riski Fitriani (2015) dengan judul Pengaruh strategi pembelajaran problem based learning dan inkuiri terbimbing terhadap keterampilan metakognitif, berpikir kritis, dan hasil belajar kognitif, hasil penelitiannya menunjukkan ada pengaruh strategi pembelajaran Problem Based Learning (PBL) terhadap hasil belajar kognitif siswa (Syahidi et al., 2020). Hasil penelitian (Yunita et al., 2020) yang berjudul Pengaruh model PBL melalui Lesson Study terhadap kemampuan berfikir kritis siswa dimana hasil penelitiannya ada pengaruh model pembelajaran Problem Based Learning melalui Lesson Study terhadap kemampuan berpikir kritis siswa pada materi usaha dan energi kelas X SMA Al-Hamzar Tembeng Putik Tahun pelajaran 2016/2017”.

\section{KESIMPULAN}

Dari hasil analisis data maka dapat ditarik kesimpulan antara kelas kontrol yang menggunakan model pembelajaran konvensional dan kelas eksperimen yang menggunakan model pembelajaran PBL mengalami perbedaan nilai rata- rata. Nilai rata- rata kelas kontrol sebesar 65.48 sedangkan nilai rata- rata kelas eksperimen sebesar 85.48 dengan selisih skor sebesar 20. Perhitungan hipotesisnya $\boldsymbol{t}_{\text {hitung }}=2,042$ sedangkan $\boldsymbol{t}_{\text {tabel }}=1,079$ dari hasil perhitungan uji hipotesis hasil belajar IPA siswa didapatkan nilai $\boldsymbol{t}_{\boldsymbol{h i t u n g}}>\boldsymbol{t}_{\boldsymbol{t a b e l}}$, didapatkan hasil $H_{a}$ diterima yang berbunyi "Penerapan model pembelajaran Problem Base Learning (PBL) pada pembelajaran IPA di SMPN 3 Selong" $H_{o}$ ditolak. Hal ini dapat disimpulkan bahwa ada pengaruh dalam penerapan model pembelajaran PBL dalam pembelajaran IPA di SMP 3 Selong.

\section{SARAN}

Diharapkan untuk penelitian- penelitian selanjutnya apabila menggunakan model pembelajaran yang sama akan mendapatkan nilai yang lebih baik lagi dan para guru di Indonesia khususnya di Lombok Timur lebih berani mengembangkan inovasi dan kreasinya dalam menggunakan model pembelajaran yang tepat dalam pembelajaran IPA. 


\section{UCAPAN TERIMA KASIH}

Ucapan terima kasih diucapkan untuk kepala sekolah SMPN 3 Selong yang telah memberikan tempat untuk meneliti di sekolah dan para guru bidang studi khususnya IPA yang telah membantu berjalannya proses penelitian sehingga bisa selesai tepat waktu.

\section{DAFTAR PUSTAKA}

Syahidi, K., Hizbi, T., Hidayanti, A., Ditinjau, B., Kemampuan, D., \& Kritis, B. (2020). The Effect of PBL Model Based Local Wisdom Towards S tudent's Learning Achievements on Critical Thinking Skills Pengaruh Model PBL Berbasis Kearifan Lokal Terhadap Prestasi. Kasuari: Physics Education Journal ( KPEJ) Universitas Рариа, 3(1), 61-68.

Yunita, N., Zahara, L., \& Syahidi, K. (2020). Pengaruh Model Problem Based Learning (PBL) Melalui Lesson Study Terhadap Kemampuan Berpikir Kritis Siswa. Kappa Journal, 4(2), 233-239. https://doi.org/10.29408/kpj.v4i2.2756

Arends, R. I. (2008). Belajar untuk mengajar. (Terjemahan Helly Prajitno Soetjipto \& Sri Mulyantini Soetjipto). New York: McGraw Hills. (Buku asli diterbitkan tahun 2007).

Lestari, N. N. (2012). Pengaruh Model Pembelajaran Berbasis Masalah (Problem- Based Learning) Dan Motivasi Belajar Terhadap Prestasi. Jurnal Teknologi Pembelajaran Indonesia, 1(2), 1-21.

Mujakir. (2015). Kreativitas Guru Dalam Pembelajaran IPA di Sekolah Dasar. Lantanida Journal Vol 3, No.1. 2015.

Ni, Made (2008). Penerapan Model Problem Based Learning untuk Meningkatkan Partisipasi Belajar dan Hasil Belajar Teori Akuntansi Mahasiswa Jurusan Ekonomi Undiksha Laporan Penelitian. Hlm 74-84.

Nisaul dkk. Penerapan Model Pembelajaran Problem Based Learning (PBL) untuk meningkatkan belajar siswa kelas X-3 pada mata pelajaran sosiologi SMA Negeri Kebakkramat Tahun Ajaran 2015/2016. 2016.

Rikawati, Julia., Kresnadi, Hery., Margiati, K, Y. 2014. Peningkatan Hasi Belajar Siswa Pada Pembelajaran IPA Menggunakan Metode Eksperimen Kelas V Sekolah Dasar. S.Pd Skripsi. Universitas Tanjungpura Pontianak.

Riski Fitriyani, Aloysius Duran Corebima, Ibrohim Ibrohim. (2015). Pengaruh strategi pembelajaran problem based learning dan inkuiri terbimbing terhadap keterampilan metakognitif, berpikir kritis, dan hasil belajar kognitif siswa sma. Jurnal Pendidikan Sains. Vol 3 No 4. 2015. journal.um.ac.id

Trianto. (2010). Pendidikan Nasionali. Jakarta: Erlangga.

Yuliani, Hatma. (2021). Penerapan Problem Based Learning (PBL) dengan Pemberian Biografi Ilmuwan Pada Mata Kuliah Fisika Dasar I: Dampak Sikap Ilmiah dan Motivasi belajar. Kappa Journal, Pendidikan Fisika FMIPA Universitas Hamzanwadi, Juni 2021. Vol. 5, No.1 